\title{
Common Long-Horned Bee Melissodes communis Cresson (Insecta: Hymenoptera: Apidae: Apinae) ${ }^{1}$
}

\author{
Nicole Miller and Cameron Jack ${ }^{2}$
}

\section{Introduction}

Melissodes communis (Cresson) is a solitary bee known as the common long-horned bee. The genus Melissodes consists of five species, with Melissodes communis being the most widely distributed species of the genus. This bee is found across North and Central America and can be identified by its extending long antennae (Figure 1). First characterized in 1878 by Cresson, the common long-horned bee is a frequent pollinator of wildflowers throughout the United States (Cardel et al. 2010).

\section{Distribution}

Melissodes communis is relatively understudied considering its large geographical range. The bee has been identified in northwestern Canada, across the continental United States, and as far south as the southern tip of Mexico (Figure 2). Its vast range could possibly be attributed to its ability to withstand many different climates.

\section{Description}

The common long-horned bee is typically 9 to $15 \mathrm{~mm}$ in total length and has yellowish wings. The bee can be identified by its long antennae that can span from its head, past the waist, to the abdomen. It is typically more active during the fall months. Females of the species can be identified by their extremely hairy scopa located on their lower back

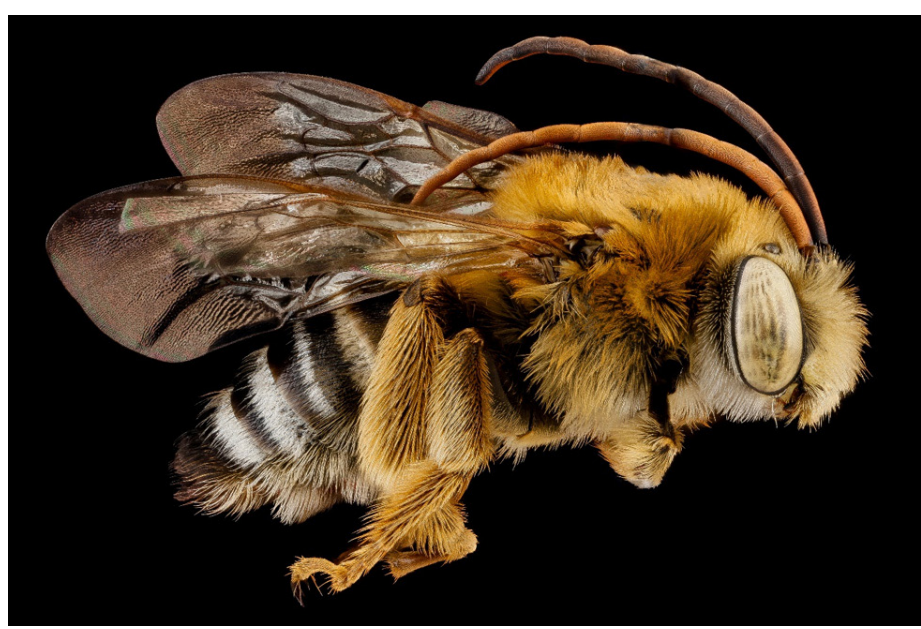

Figure 1. The common long-horned bee, Melissodes communis (Cresson), is known for its antennae that can extend all the way to its abdomen.

Credits: Sam Droege (sdroege@usgs.gov), United States Geological Survey

abdomen (Figure 3). The scopa is used to collect and store pollen to be transported back to the nest.

To date, little is known about the life cycle of Melissodes communis. Melissodes microsticta has been found to fill nests with seven to 11 eggs (Miliczky 2000). Melissodes rustica has been found to fill nests with only one egg (Cameron et al. 1996). The total number of eggs laid per nest by Melissodes communis is unknown. In general, mature Melissodes brood are around 6 to $8 \mathrm{~mm}$ wide and 10

1. This document is EENY-756, one of a series of the Entomology and Nematology Department, UF/IFAS Extension. Original publication date May 2020. Visit the EDIS website at https://edis.ifas.ufl.edu for the currently supported version of this publication. This document is also available on the Featured Creatures website at http://entomology.ifas.ufl.edu/creatures.

2. Nicole Miller, School of Natural Resources and Environment; and Cameron Jack, Entomology and Nematology Department; UF/IFAS Extension, Gainesville, FL 32611.

The Institute of Food and Agricultural Sciences (IFAS) is an Equal Opportunity Institution authorized to provide research, educational information and other services

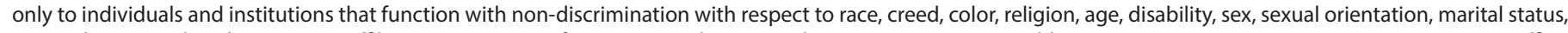

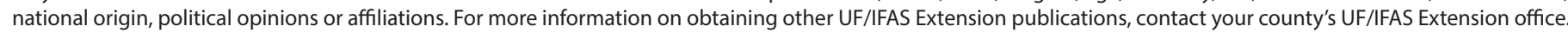
U.S. Department of Agriculture, UF/IFAS Extension Service, University of Florida, IFAS, Florida A \& M University Cooperative Extension Program, and Boards of County Commissioners Cooperating. Nick T. Place, dean for UF/IFAS Extension. 


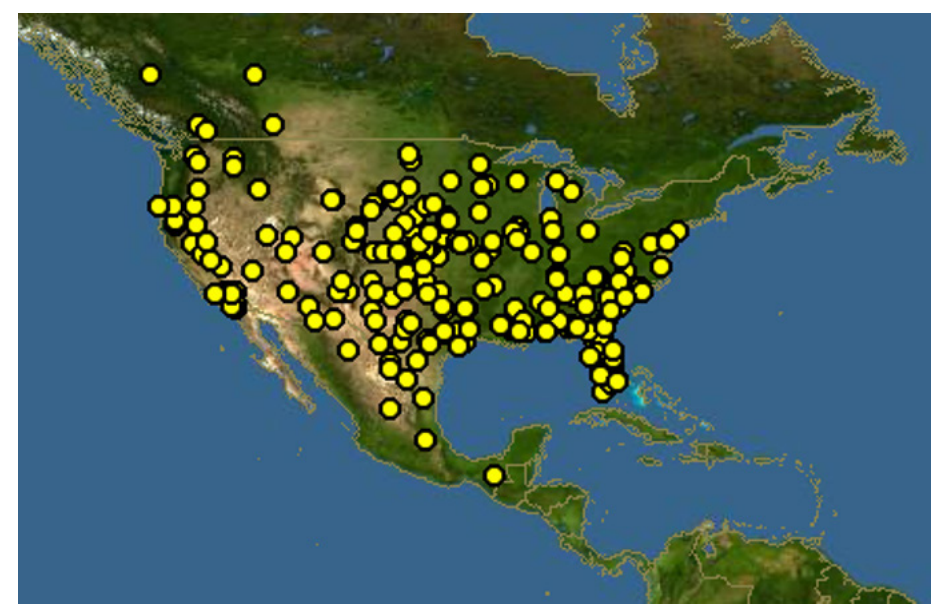

Figure 2. Identification points of Melissodes communis Cresson, collected from North and Central America.

Credits: Map provided by DiscoverLife.org

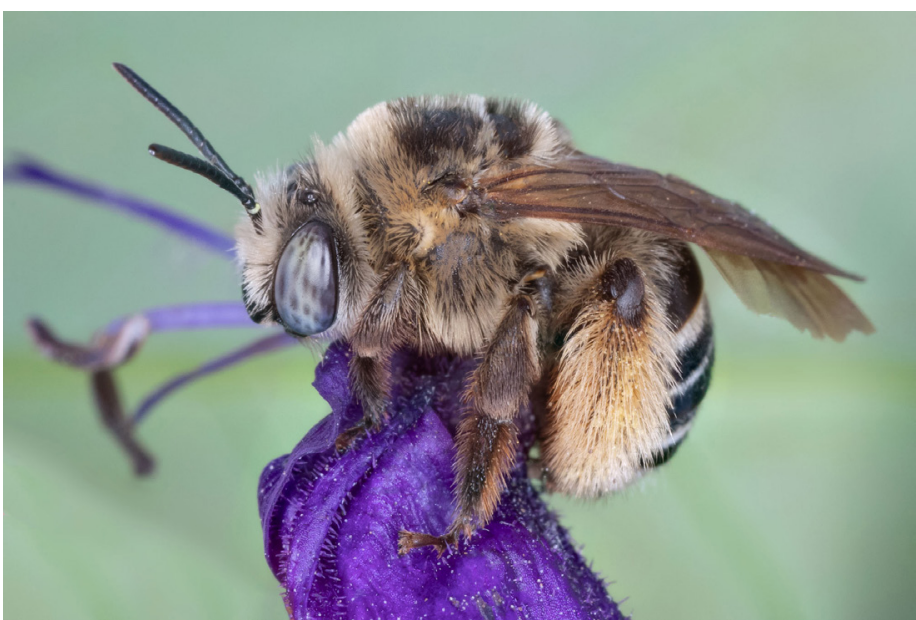

Figure 3. Female long-horned bees, Melissodes communis Cresson, are known to have extremely hairy scopas located on their lower back abdomen.

Credits: Paula Sharp, https://www.wildbeestexas.com/

to $15 \mathrm{~mm}$ in length (Clement 1973). The species is proposed to be univoltine, meaning adult bees brood offspring only once per life cycle. Larvae will pupate before emerging as adults from the nest. Adult bees are active for about one month during which they forage, settle to copulate, and nest (Cameron et al. 1996).

\section{Biology}

Melissodes communis nests underground. There is still much that we do not know about the biology of Melissodes communis, but $\sim 90 \%$ of the genus Melissodes is composed of solitary bees (Cameron et al. 1996). Solitary bees do not form colonies and therefore build individual nests. Solitary female bees construct nests alone, without assistance from the males. These nests provide an environment in which their larvae can grow. Females collect pollen to feed to developing larvae.
Little is known of the nesting patterns of Melissodes communis; however, other species of the genus have been found to nest in dry soils, composed of rock or sand. Melissodes rustica, a related species, has been found to burrow and mate during the late summer months, from July to September. Melissodes rustica females nest singularly in burrows, while males tend to aggregate in small clusters in older burrows or rocky crevices. In order to excavate nests, female Melissodes rustica bees use mandibles and forelegs to remove large soil particles. The nests are typically located in topsoil and can contain a small extension, where soil is compacted to prevent the remainder of the nest from filling with surface debris (Figure 4) (Clement 1973). Nest cells are provisioned with pollen for bee brood (Cameron et al. 1996).

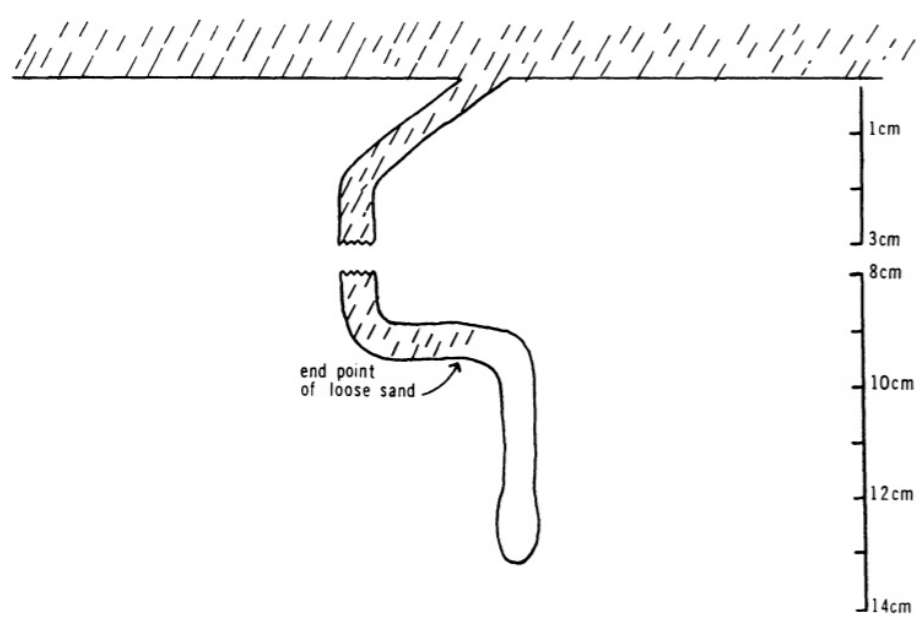

Figure 4. Melissodes rustica Say nest structure (Clement 1973).

\section{Host Plants}

The common long-horned bee is a major pollinator for wildflowers throughout the United States (Figure 5). Bees within the genus Melissodes have been found on over 50 wildflower genera throughout the United States, including ironweeds, sneezeweeds, passionflowers, sweet clovers, and mountain mint (LaBerge 1956). Melissodes communis has been known to utilize pollen from flowers in the squash, mustard, sunflower, blueberry, Crepe Myrtle, and primrose families throughout Florida (Johnson 2016). Melissodes communis has also been found to be a major pollinator of the flower Proboscidea louisianica in the western United States (Cardel et al. 2010).

\section{Economic Impact}

Melissodes communis is a pollinator of economically important crops such as squash, mustard, sunflower, blueberry, Crepe Myrtle, and primrose; however, the effect Melissodes communis pollination has on produce industries 


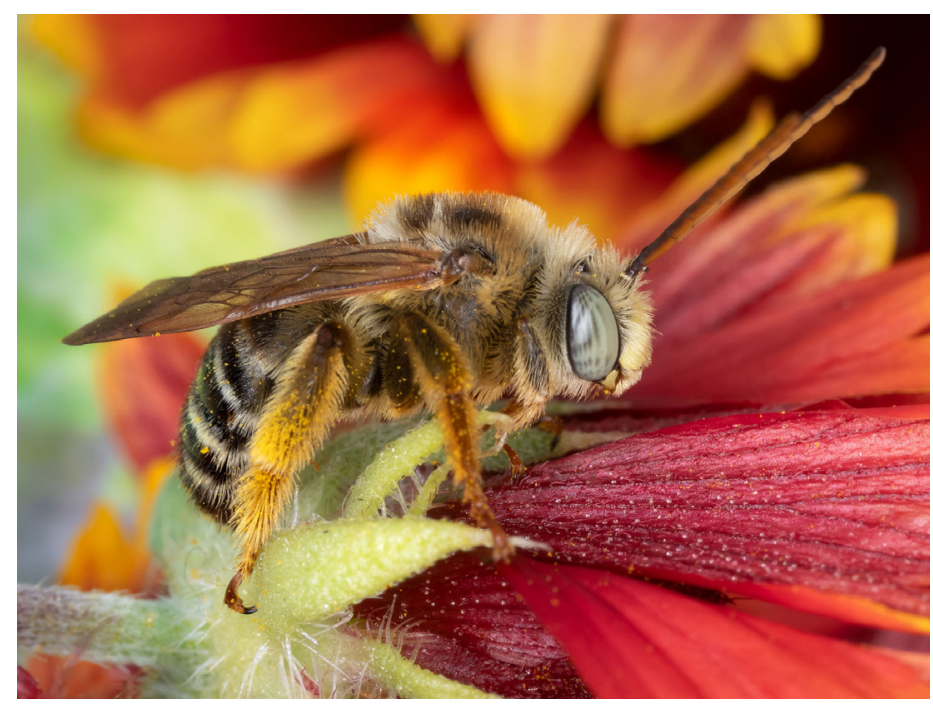

Figure 5. A male common long-horned bee, Melissodes communis Cresson on the North American wildflower Gaillardia pulchella Fouger. Credits: Paula Sharp, https://www.wildbeestexas.com/

in North America is unknown. Melissodes communis prefers wildflowers to fruiting plants. Therefore, the species could possibly play a major role in influencing community dynamics and pollination in less developed areas of its natural habitat. The bee's ecological services have yet to be studied intensively.

\section{Selected References}

Cameron SA, Whitfield JB, Hulslander CL, Cresko WA, Isenberg SB, King RW. 1996. "Nesting biology and foraging patterns of the solitary bee Melissodes rustica (Hymenoptera: Apidae) in northwest Arkansas." Journal of the Kansas Entomological Society 69:260-273.

Cardel YJ, Koptur S. 2010. "Effects of florivory on the pollination of flowers: An experimental field study with a perennial plant." International Journal of Plant Sciences 171:283-292.

Clement SL. 1973. "The nesting biology of Melissodes (Eumelissodes) rustica (Say), with a description of the larva (Hymenoptera: Anthophoridae)." Journal of the Kansas Entomological Society 46:516-525.

Hall HG, Ascher JS. 2010. "Surveys of bees (Hymenoptera: Apoidea: Anthophila) in natural areas of Alachua County in north-central Florida." Florida Entomologist 93:609-630.

Johnson RD. 2016. Wild Bee Species Richness on North Central Florida Produce Farms: Interactions of Wild Bees with Landscape, Farm Vegetation, and Flower Pollen. Ph.D. Dissertation. University of Florida, Gainesville, FL, 116 pp.
LaBerge WE. 1961. "A revision of the bees of the genus Melissodes in North and Central America. Part III (Hymenoptera, Apidae)." University of Kansas Science Bulletin 42:283-663.

Miliczky E. 2000. "Nesting biology of the bee Melissodes (Eumelissodes) microsticta Cockerell in Washington state (Hymenoptera: Apidae)." Pan-Pacific Entomologist 76:184-196.

Phillippi A, Tyrl RJ. 1979. "The reproductive biology of Proboscidea louisianica (Martyniaceae).” Rhodora 81:345-361. 